\title{
Effect of cimetidine on ion fluxes and potential difference across the human stomach
}

\author{
K. J. IVEY ${ }^{1}$, AND P. A. MACKERCHER \\ From the Department of Medicine, Harry. S. Truman Memorial Veterans Hospital and University of \\ Missouri, Columbia, Missouri, USA
}

SUMMARY The $\mathbf{H}_{2}$-receptor antagonist, cimetidine, reduces acid output regardless of the means of stimulation. It is not known in man whether this is due entirely to a reduction in acid secretion or whether increased back diffusion of hydrogen ions is also occurring. We studied fluxes of $\mathrm{H}^{+}, \mathrm{Na}^{+}$, $\mathrm{K}^{+}$, and $\mathrm{Cl}^{-}$ions after acid instillation into the human stomach in six healthy subjects with and without prior administration of $300 \mathrm{mg}$ cimetidine orally. Potential difference across gastric mucosa was measured continuously throughout each study. Cimetidine caused a significant reduction in hydrogen ion secretion $(5.05 \mathrm{mEq}$ per 15 minutes controls versus 2.70 cimetidine, $\mathrm{P}<0.05)$, and consequently a significant reduction in net hydrogen flux into the gastric lumen $(2.01 \mathrm{mEq}$ per 15 minutes versus $0.02, \mathrm{P}<0.05$ ). There were no significant differences between sodium ion fluxes in control and cimetidine studies, suggesting that the gastric mucosal barrier remained intact. Cimetidine alone caused a highly significant rise in intragastric $\mathrm{pH}$ (to 7$)$ and of potential difference $(\mathrm{P}<0.001)$. Addition of intragastric acid $(\mathrm{pH}<1.0)$ did not reverse the rise in potential difference caused by cimetidine, suggesting that factors other than change in intragastric $\mathrm{pH}$ were involved. In conclusion, our studies support the concept that reduction in acid output by cimetidine is due to inhibition of acid secretion, and not to increased permeability to hydrogen ion.

Changes in acid secretion cannot satisfactorily explain gastric mucosal damage associated with conditions such as gastric ulcer or acute aspirininduced mucosal damage. The ill-defined concept of mucosal resistance has long been used to explain such cases. An attempt to define and measure this resistance objectively was the 'gastric mucosal barrier' concept popularised by Davenport (1970); Ivey (1971); Code et al. (1963); and Reitemeier et al. (1957). Davenport found that topical aspirin induced an increase in the net fluxes of $\mathrm{Na}^{+}$ions into the gastric lumen and at the same time of $\mathrm{H}^{+}$ ions out. Increased net movement of $\mathrm{Na}^{+}$ions into the lumen and of $\mathrm{H}^{+}$ions out was termed 'alteration' or 'damage' to the 'gastric mucosal barrier' which limited potentially damaging $\mathrm{H}^{+}$ion movement into the gastric mucosa. In Davenport's studies, alteration of net $\mathrm{Na}^{+}$and $\mathrm{H}^{+}$fluxes was associated with a fall in PD. Other workers (Chvasta and Cooke, 1972) confirmed this, and so changes in PD became

\footnotetext{
${ }^{1}$ Address for reprint requests: Kevin J. Ivey, University of Missouri, Department of Medicine, Division of Gastroenterology, Columbia, Missouri 65201, USA.
}

Received for publication 10 January 1978 to be used as a measure of 'gastric mucosal barrier' damage.

The new $\mathrm{H}_{2}$-receptor antagonist, cimetidine, has been shown to reduce acid output significantly in man, given orally. It is important to determine whether some of this reduced acid output is due to increased back-diffusion of $\mathrm{H}^{+}$ions.

The purpose of this paper is to present new data on the effect of oral cimetidine on net ion fluxes and PD changes after acid instillation in man. In addition, the literature on the effect of the $\mathrm{H}_{2}$-blockers on the gastric mucosal barrier as measured by ion fluxes and potential difference will be summarised briefly for all species.

\section{Methods}

The study was carried out on six healthy volunteers, aged 21-28 years, who gave informed consent. The study was approved by the institutional Human Experimentation Committee. All six subjects were studied twice on separate dates, usually one week apart. One study was the control study with intragastric acid test solution, and the other was the same study, but with a single oral $300 \mathrm{mg}$ dose of 
cimetidine given one hour beforehand. In some subjects the control study was done first, and in others the cimetidine was done first. The results were similar regardless of the order of the studies.

\section{TEST SOLUTION}

The test solution was $160 \mathrm{mmol} / 1 \mathrm{HCl}$ with a mean $\mathrm{pH}$ of 0.89 and osmolality of $307 \mathrm{~m} 0 \mathrm{sm} / \mathrm{kg}$ containing radioactive chromium chloride ${ }^{51} \mathrm{Cr} \mathrm{Cl}_{3}$ $25 \mu \mathrm{Ci} / \mathrm{l})$ as non-absorbable indicator. A wash solution contained $160 \mathrm{mmol} / \mathrm{l} \mathrm{HCl}$ only.

\section{POTENTIAL DIFFERENCE}

Gastric mucosal potential difference was measured by a previously described technique (Ivey et al., 1975; Andersson and Grossman, 1965; Baskin et al., 1976; Ivey and Settree, 1976) using intravenous and intragastric electrodes filled with a saturated $\mathrm{KCl}$ solution in $3 \%$ agar. Continuous recordings were made by means of a strip chart recorder.

At the beginning of each study, fasting gastric contents were aspirated and $\mathrm{pH}$ was determined on each sample with a Beckman Expandometric pH meter (Beckman Instruments, Inc., Fullerton, California). The stomach was next washed with $200 \mathrm{ml}$ normal saline and aspirated to remove residual contents. Potential difference recording was begun after instillation of $100 \mathrm{ml}$ normal saline to establish a basal control period of $\mathbf{3 0}$ minutes.

EXPERIMENTAL TECHNIQUE, LABORATORY MEASUREMENTS AND CALCULATIONS FOR ION FLUX STUDIES

These have been described in detail elsewhere (Ivey and Clifton, 1971). After baseline PD was established, $200 \mathrm{ml}$ of acid test solution was instilled into the stomach via a nasogastric tube. This was mixed rapidly and sampled. Exactly 15 minutes later, gastric contents were aspirated as fully as possible, and the residual volume then recovered by rinsing with wash solution. Because of our previous finding (Ivey and Schedl, 1970) of adsorption of indicator to gastric mucosa during the first 15 minute period of exposure to test solution, samples from this period were discarded. Each subject was then studied with the acid test solution for one or two periods per study. Volume secreted and volume passing through the pylorus (volume emptied) were calculated using ${ }^{51} \mathrm{Cr}$ as a non-absorbable indicator (Hunt, 1951; Ivey and Schedl, 1970). Net ion fluxes were determined by the formula (Davenport, 1970; Ivey and Clifton, 1971):

Net ion flux $=$ ion recovered + ion emptied - ion initial. On the basis of Hollander's two component hypothesis (Hollander, 1952) the gastric secretion was divided into a parietal and non- parietal component as described by Chapman $e t$ al. (1968). From this the amounts of $\mathrm{H}^{+}$secreted, and $\mathrm{H}^{+}$neutralised by bicarbonate per 15 minutes can be derived. The net flux value can then be corrected for this secretion and a 'corrected flux' value for $\mathrm{H}^{+}$and $\mathrm{Cl}^{-}$ion calculated per 15 minute period by:

Corrected flux $\mathrm{H}^{+}=$net flux $\mathrm{H}^{+}+\mathrm{H}^{+}$

neutralised $-\mathrm{H}^{+}$secreted

Corrected flux $\mathrm{Cl}^{-}=$net flux $\mathrm{Cl}^{-}-\mathrm{Cl}^{-}$non-

parietal secretion $-\mathrm{Cl}^{-}$parietal secretion.

A positive flux indicates a net addition of ions to the lumen. A negative flux indicates a net loss of ion from the lumen. For full details of the calculations of these formulae, including the errors inherent in the calculation of 'corrected $\mathbf{H}^{+}$flux', the reader is referred to our earlier work (Ivey and Clifton, 1971).

All samples were tested for bilirubin by Ictotest tablets, and samples heavily stained by bile were discarded.

In the cimetidine studies, once baseline PD values had been established (at time -60 minutes, Figure), a $300 \mathrm{mg}$ cimetidine tablet was taken orally in $100 \mathrm{ml}$ normal saline and PD recorded continuously for the next 60 minutes when gastric contents were aspirated. Acid test solution was then instilled as for the control studies.

STATISTICAL ANALYSIS

Results were analysed statistically by use of the paired Student's $t$ test.

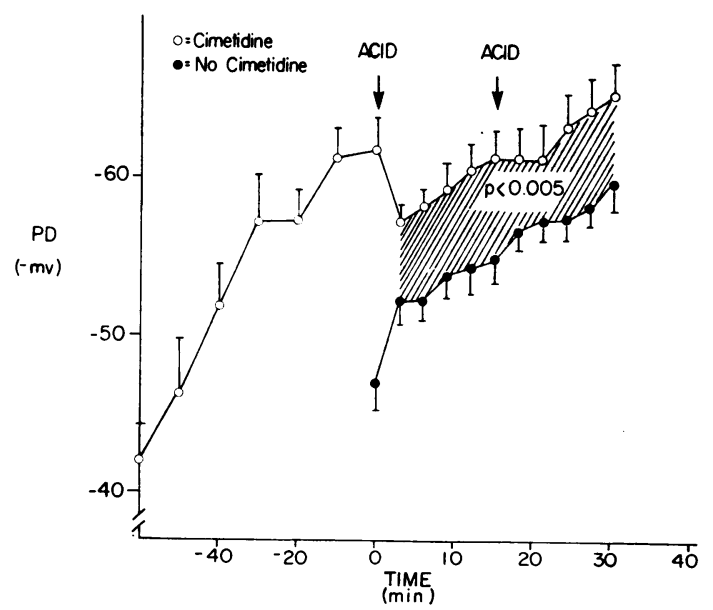

Figure. Effect of cimetidine alone, cimetidine plus intragastric acid, and intragastric acid alone on gastric mucosal potential difference. $P D$ is shown on the vertical axis in millivolts (mucosal PD is negative to serosal); time is on the horizontal axis in minutes. Cimetidine was administered orally at -60 minutes. 
Table Ionic movement and volumes secreted and emptied from stomach contents in control and cimetidine studies $($ mean $\pm S E)$

\begin{tabular}{|c|c|c|c|c|c|c|c|c|c|c|c|}
\hline \multirow[t]{2}{*}{ Study } & \multirow[t]{2}{*}{ Subjects } & \multirow[t]{2}{*}{$n$} & \multicolumn{3}{|c|}{$\begin{array}{l}\text { Net flux } \\
(\mathrm{mEq} / 15 \mathrm{~min})\end{array}$} & \multirow[b]{2}{*}{$\mathrm{Cl}^{-}$} & \multicolumn{2}{|c|}{$\begin{array}{l}\text { Corrected flux } \\
(\mathrm{mEq} / 15 \mathrm{~min})\end{array}$} & \multicolumn{2}{|c|}{$\begin{array}{l}\text { Volume } \\
(\mathrm{ml} / 15 \mathrm{~min})\end{array}$} & \multirow{2}{*}{$\begin{array}{l}\begin{array}{l}H^{+} \text {Secreted } \\
(\mathrm{mEq} / 15 \text { min })\end{array} \\
H S\end{array}$} \\
\hline & & & $\mathrm{H}^{+}$ & $\mathrm{Na}^{+}$ & $K^{+}$ & & $\mathrm{H}^{+}$ & $\mathrm{Cl}^{-}$ & Secreted & Emptied & \\
\hline $\begin{array}{c}\text { Control } \\
\pm S E\end{array}$ & 6 & 9 & $\begin{array}{l}2 \cdot 01 \\
0 \cdot 67\end{array}$ & $\begin{array}{l}1 \cdot 67 \\
0 \cdot 23\end{array}$ & $\begin{array}{l}0.48 \\
0.12\end{array}$ & $\begin{array}{l}3 \cdot 67 \\
0.84\end{array}$ & $\begin{array}{r}-2 \cdot 77 \\
0 \cdot 70\end{array}$ & $\begin{array}{r}-2 \cdot 77 \\
0.61\end{array}$ & $\begin{array}{r}43 \cdot 0 \\
8 \cdot 0\end{array}$ & $\begin{array}{r}33 \cdot 0 \\
9 \cdot 0\end{array}$ & $\begin{array}{l}5 \cdot 05 \\
1 \cdot 12\end{array}$ \\
\hline $\begin{array}{l}\text { Cimetidine } \\
\pm S E\end{array}$ & 6 & 9 & $\begin{array}{l}0.02 * \\
0.47\end{array}$ & $\begin{array}{l}2 \cdot 06 \\
0 \cdot 27\end{array}$ & $\begin{array}{l}0.38 \\
0.08\end{array}$ & $\begin{array}{l}2 \cdot 10 \\
0 \cdot 56\end{array}$ & $\begin{array}{r}-2 \cdot 30 \\
0.74\end{array}$ & $\begin{array}{r}-2 \cdot 48 \\
0.74\end{array}$ & $\begin{array}{r}32 \cdot 0 \\
3 \cdot 0\end{array}$ & $\begin{array}{r}51 \cdot 0 \\
9 \cdot 0\end{array}$ & $\begin{array}{l}2 \cdot 70^{*} \\
0 \cdot 33\end{array}$ \\
\hline
\end{tabular}

$* \mathbf{P}<0.05$.

$\mathbf{n}=$ total number of periods studied.

\section{Results}

\section{ION FLUXES}

In the Table are shown data for net fluxes of $\mathbf{H}^{+}$, $\mathrm{Na}^{+}, \mathrm{K}^{+}$, and $\mathrm{Cl}^{-}$as well as 'corrected fluxes' of $\mathrm{H}^{+}$and $\mathrm{Cl}^{-}$ions and the calculated amount of $\mathrm{H}^{+}$ secreted during the study. The net flux of $\mathrm{H}^{+}$ions into the gastric lumen was significantly less after cimetidine than in controls. The mean amount of $\mathrm{H}^{+}$secreted during the control study, $5.05 \mathrm{mEq}$ per 15 minutes, was significantly greater than that of $2.70 \mathrm{mEq}$ during the cimetidine study. The difference between these two sums approximates the mean difference between the net fluxes of $\mathrm{H}^{+}$ions so that the 'corrected $\mathrm{H}^{+}$fluxes'-that is, net $\mathrm{H}^{+}$flux corrected for $\mathrm{H}^{+}$secretion during the study-for control and cimetidine studies were similar, $-2 \cdot 77$ and $-2.30 \mathrm{mEq} / 15$ minutes respectively. This suggests that the lower net flux after cimetidine was due to a mean reduction of acid secreted rather than to back diffusion of $\mathrm{H}^{+}$ions. There were no significant differences for $\mathrm{Na}^{+}$ion fluxes between control and cimetidine studies. This is further support that the difference between control and cimetidine studies is not due to altered ionic permeability-that is, a change in the gastric mucosal barrier.

\section{POTENTIAL DIFFERENCE}

PD values are shown in the Figure. With cimetidine and intragastric normal saline, there was a significant rise in PD over the hour following its administration from $-42 \pm 2 \mathrm{mV}$ to $-62 \pm 2 \mathrm{mV}(\mathrm{P}<0.001)$. Gastric $\mathrm{pH}$ rose significantly also from mean $\mathrm{pH}$ 2 to $\mathrm{pH} 7$.

Intragastric instillation of $160 \mathrm{mmol} / 1 \mathrm{HCl}$ into the stomach also produced a significant rise in PD over the saline baseline from $-47+2 \mathrm{mV}$ to $-60 \pm 2 \mathrm{mV}(\mathrm{P}<0.001)$.

When acid was instilled intragastrically 60 minutes after cimetidine administration (intragastric $\mathrm{pH} \mathrm{7),}$ there was a transient small fall in PD during the first three minutes of instillation from -62 to $-57 \mathrm{mV}(\mathrm{P}<0.05)$. Values then rose back to their original levels over the next 15 minutes, and to above cimetidine and saline values at the end of 30 minutes (Figure). The difference between values at three minutes and 30 minutes was highly significant $(P<0.005)$. Comparing values of the curves for intragastric acid alone and acid plus cimetidine, PD values with cimetidine were significantly higher than for acid alone $(P<0.005$, shaded area of Figure).

\section{VOLUMES}

In the Table are shown the values for volumes secreted and volumes emptied through the pylorus during control and cimetidine studies. The mean volume emptied during the cimetidine study, $51 \pm 9 \mathrm{ml}$, was greater than for the control period, $33 \pm 9$, but the differences were not significant. The mean volume secreted during the cimetidine study $(32.0 \mathrm{ml})$ was less than during the control study (43 $\mathrm{ml})$, but not significantly so.

\section{Discussion}

Our findings of a smaller net $\mathrm{H}^{+}$flux into the gastric lumen after oral cimetidine compared to controls without significant increase in $\mathrm{Na}^{+}$flux are consistent with the findings previously reported in man with intravenous metiamide (Thjodleifsson and Wormsley, 1975). Likewise, we have concluded that this reduced value is due to reduction of $\mathrm{H}^{+}$secretion rather than to increased back diffusion of $\mathrm{H}^{+}$ions. Our findings in this respect with oral cimetidine are similar to those we previously reported with intravenous atropine (Ivey and Clifton, 1971).

In studies in chair-adapted monkeys, Dubois and his colleagues (1977) found a delay in gastric

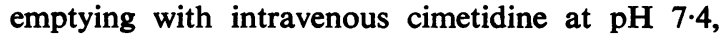
but no significant effect at $\mathrm{pH} 1$. Our studies confirm that, with a highly acid intragastric solution, 
cimetidine does not delay gastric emptying. If anything, there was a tendency towards more rapid emptying with cimetidine.

Our study shows that addition of extrinsic $\mathrm{HCl}$ to the human stomach causes a significant rise in PD. Cimetidine caused a significant rise in gastric PD when given with saline as was previously reported (Ivey et al., 1975). This was associated with a rise in gastric $\mathrm{pH}$ to 7 . Our current study shows that, even when gastric $\mathrm{pH}$ is reduced to $\mathrm{pH} 1$, cimetidine still causes a significant rise in PD. This suggests that factors other than simply alteration of intragastric $\mathrm{pH}$ are involved.

On review of the literature, a number of studies have been reported on the effect of different $\mathrm{H}_{2}$ receptor antagonists on ionic permeability and PD in vitro and in vivo. One of the most detailed studies was the in vitro study on dog fundic mucosa by Bowen et al. (1975). Burimamide added to the serosal side of the preparation had no effect on net or unidirectional fluxes of $\mathrm{Na}^{+}$or $\mathrm{Cl}^{-}$ions. On the other hand, in vitro studies on the rabbit mucosa by Fromm and his associates (1976) indicated that the fundus and antrum contained $\mathbf{H}_{2}$-receptor sites unrelated to acid secretion which governed ionic permeability. In the rabbit preparation, histamine decreased and burimamide increased mucosal permeability.

Carter and his colleagues ( $\mathrm{O}^{\prime}$ Brien and Carter, 1975; Kenyon and Carter, 1976) reported that neither intragastric metiamide nor cimetidine had an effect on net $\mathrm{H}^{+}$or $\mathrm{Na}^{+}$ion fluxes across the dog's stomach in vivo; nor did either drug prevent the barrier breaking effect of taurocholate. Similarly, metiamide prevented bile salt-induced stress ulcers during haemorrhagic shock, but had no effect on the abnormal ionic permeability (Safaie-Shirazi et al., 1976).

In patients with duodenal ulcer or oesophagitis, Thjodleifsson and Wormsley (1975) found that intravenous metiamide had no significant effect on net sodium flux, while net $\mathrm{H}^{+}$flux was decreased. This they attributed to reduction in acid secretion. Other British workers (Rees et al., 1976) found that administration of the $\mathrm{H}_{1}$-blocker mepyramine, with the $\mathrm{H}_{2}$-blocker intravenously, decreased the abnormal gastric ionic permeability induced by taurocholic acid in the dog. Neither the $\mathrm{H}_{1}-$ nor the $\mathbf{H}_{2}$-receptor antagonist given seperately had any such effect.

The $\mathrm{H}_{2}$-blockers by themselves produce a significant rise in gastric transmucosal PD. Intravenous burimamide raised PD in the dog flap (Bowen et al., 1975), but had no effect on electrical resistance. These and other findings were interpreted as indicating that $\mathrm{H}_{2}$-blockers had no effect on active ion transport, and the rise in PD was due to inhibition of $\mathrm{H}^{+}$secretion (Bowen et al., 1975).

In man, oral cimetidine produced a significant rise in gastric PD and pH (Ivey et al., 1975). While cimetidine protected gastric mucosa against aspirininduced injury, it did not prevent the fall in PD induced by aspirin in man; but because of the initial rise, PD values did not fall below control baseline levels (MacKercher et al., 1976; 1977). A recent report indicated that oral cimetidine given to rats for two days or more, but not less, reduced coldrestraint lesions in the rat. In addition, cimetidine prevented the abnormal stress-induced fall in transmucosal PD (Strauss et al., 1977a, b). While the significance of maintenance of a normal PD in these situations is uncertain, the absence of a fall in PD after $\mathbf{H}_{2}$-receptor antagonists in all studies, including our own, is further evidence that these agents do not increase gastric ionic permeability.

In conclusion, the majority of studies, including our own, have failed to find an effect of any of the $\mathrm{H}_{2}$-receptor antagonists on ionic permeability.

The authors wish to express their appreciation to Dr William N. Baskin, M. M. Burks and $\mathbf{M r}$ G. E. Jeffrey for technical assistance, and Mrs Debbie Wilson for secretarial assistance. This work was supported in part by the Medical Research Service of the VA, and the patient study facilities of the Clinical Research Center of the University of Missouri Medical Center.

\section{References}

Andersson, S., and Grossman, M. I. (1965). Profile of pH, pressure and potential difference at gastroduodenal junction in man. Gastroenterology, 19, 364-371.

Baskin, W. N., Ivey, K. J., Krause, W. J., Jeffrey, G. E., and Gemmell, R. T. (1976). Aspirin-induced ultrastructural changes in human gastric mucosa. Correlation with potential difference. Annals of Internal Medicine, 85, 299-303.

Bowen, J. C., Kuo, Y-J., Pawlik, W., Williams, D., Shanbour, L. L., and Jacobson, E. D. (1975). Electrophysiological effects of burimamide and 16,16-dimethyl prostaglandin $\mathrm{E}_{2}$ on the canine gastric mucosa. Gastroenterology, 68, 1480-1484.

Chapman, M. A., Werther, J. L., and Janowitz, H. D. (1968). Response of the normal and pathological human gastric mucosa to an instilled acid load. Gastroenterology, 55, 344-353.

Chvasta, T. E., and Cooke, A. R. (1972). The effect of several ulcerogenic drugs on the canine gastric mucosal barrier. Journal of Laboratory and Clinical Medicine, 79, 302-315.

Code, C. F., Higgins, J. A., Moll, J. C., Orvis, A. L., and Scholer, J. F. (1963). The influence of acid on the gastric absorption of water, sodium and potassium. Journal of Physiology, 166, 110-119.

Davenport, H. W. (1970). Back diffusion of acid through the 
gastric mucosa and its physiological consequences. In Progress in Gastroenterology, Vol. 2, p. 42-56. Edited by G. Jerzy-Glass. Grune and Stratton: New York.

Dubois, A., Hamilton, B., and Castell, D. O. (1977). Histamine $_{2}$ receptor involvement in the regulation of gastric emptying (Abstract). Gastroenterology, 72, 1051.

Fromm, D., Silen, M., and Robertson, R. (1976). Histamine effects on $\mathrm{H}^{+}$permeability by isolated gastric mucosa. Gastroenterology, 70, 1076-1081.

Hollander, F. (1952). Gastric secretion of electrolytes. Federation Proceedings, 11, 706.

Hunt, J. N. (1951). The secretory pattern of the stomach of man. Journal of Physiology, 113, 169-184.

Ivey, K. J. (1971). Gastric mucosal barrier. Gastroenterology, 61, 247-257.

Ivey, K. J., Baskin, W., and Jeffrey, G. (1975). Effect of cimetidine on gastric potential difference in man. Lancet, 2, 1072-1073.

Ivey, K. J., and Clifton, J. A. (1971). Ionic movement across the gastric mucosa of man: reproducibility and effect of intravenous atropine. Journal of Laboratory and Clinical Medicine, 78, 753-764.

Ivey, K. J., and Schedl, H. P. (1970). Gastric nonabsorbable indicators for studies in man. Gastroenterology, 59, 234-239.

Ivey, K. J., and Settree, P. (1976). Effect of paracetamol (acetaminophen) on gastric ionic fluxes and potential difference in man. Gut, 17, 916-919.

Kenyon, G., and Carter, D. C. (1976). The effect of the histamine $\mathrm{H}_{2}$-receptor on canine gastric mucosal barrier (Abstract). Gut, 17, 388.

MacKercher, P. A., Ivey, K. J., Baskin, W. N., and Krause,
W. J. (1977). Protective effect of cimetidine on aspirininduced gastric damage. Annals of Internal Medicine, 87, 676-679.

MacKercher, P. A., Ivey, K. J., Baskin, W. N., Krause, W., and Jeff rey, G. E. (1976). Effect of cimetidine on aspirininduced human gastric mucosal damage (Abstract). Gastroenterology, 70, 912.

O'Brien, P. E., and Carter, D. C. (1975). Effect of gastric secretory inhibitors on the gastric mucosal barrier. Gut, $16,437-442$.

Rees, W. D. W., Rhodes, J., Wheeler M. H., Meek, M. E., and Newcombe, R. G. (1976). Role of histamine receptors in the pathophysiology of gastric mucosal damage (Abstract). Gut, 17, 388.

Reitemeier, R. J., Code, C. F., and Orvis, A. L. (1957). Barrier offered by gastric mucosa of healthy persons to absorption of sodium. Journal of Applied Physiology, 10, 261-266.

Safaie-Shirazi, S., Foster, L. D., and Hardy, B. M. (1976). The effect of metiamide, an $\mathrm{H}_{2}$-receptor antagonist, in the prevention of experimental stress ulcers. Gastroenterology, 71, 421-425.

Strauss, R., Stein, T., and Wise, L. (1977a). Prevention of stress ulcerations using $\mathrm{H}_{2}$-receptor antagonists. Program of Digestive Disease Week, 23-26 May, Toronto, Canada, p. A45.

Strauss, R., Stein, T., and Wise, L. (1977b). Prevention of stress ulcerations using $\mathrm{H}_{2}$-receptor antagonists. American Journal of Surgery. (In press.)

Thjodleifsson, B., and Wormsley, K. G. (1975). Effects of metiamide on the human stomach. Clinical Science and Molecular Medicine, 49, 445-458. 